\title{
Histone Antibody Measurement
}

National Cancer Institute

\section{Source}

National Cancer Institute. Histone Antibody Measurement. NCI Thesaurus. Code

C111209.

A measurement of histone antibodies present in a sample. 